\title{
Influence of rest-rotation cattle grazing on mule deer and elk habitat use in east-central Idaho
}

\author{
JEFFREY J. YEO, JAMES M. PEEK, WILLIAM T. WITTINGER, AND CRAIG T. \\ KVALE
}

Authors are research scientist and professor, Dept. of Fish and Wildlife Resources, University of Idaho, Moscow 83843; resource staff officer, Flathead National Forest, Kalispell, Mont. 59901; and game manager, Idaho Dept. of Fish and Game, Jerome, Ida. 83338.

\begin{abstract}
Elk (Cervus elaphus Linnaeus), mule deer (Odocoileus hemionus Rafinesque), and cattle (Bos taurus Linnaeus) distributions were determined year round from 1975-1979 on a rest-rotation grazing system established in steep mountainous terrain. Following implementation of the grazing system, cattle progressively used higher elevations and steeper slopes in each succeeding year. Elk preferred rested pastures during the grazing season (June-October) and avoided habitat frequented by cattle by using higher elevations and steeper slopes. Few mule deer used the allotment during summer, but during the winter, deer selected habitats grazed previously by cattle. Elk appeared to adjust to the grazing system by making greater use of pastures with cattle present, although preference for pastures without cattle continued.
\end{abstract}

Key Words: mule deer, elk, cattle, rest-rotation grazing, Idaho

Rest-rotation grazing systems (Hormay and Talbot 1961) have been established on mountain rangelands in the northern Rocky Mountains grazed by livestock as a means of improving their condition and productivity. Many of these systems are on mountainous terrain where cattle (Bos taurus Linnaeus) typically concentrate activities on lower slopes and bottoms (Mueggler 1965), and where season-long use may deplete forage (Stoddart et al. 1975). Efforts to redistribute cattle with salt, water development, and fencing away from riparian zones often accompany the establishment of a grazing system. Rest-rotation grazing is well adapted to mountainous terrain, improving use of upland areas (Holechek et al. 1989). Mule deer (Odocoileus hemionus hemionus Rafinesque) and elk (Cervus elaphus nelsoni Linnaeus) typically prefer upper slopes and ridgetops (Julander and Jeffery 1964, Mackie 1970) and may be displaced by such practices (Skovlin et al. 1968). Concentration of cattle into smaller pastures, albeit for shorter periods, thus has caused concern that wildlife will be adversely affected (West. Assoc. State Game \& Fish Comm. 1974).

Rest-rotation grazing systems should favor increases in grasses, whereas shrubs should decline in abundance (Hormay and Talbot 1961). Mackie (1978) concluded that these grazing systems should favor elk rather than mule deer over the long term because of their differences in food habits.

In 1975, the Challis National Forest and Bureau of Land Management initiated a 3 pasture rest-rotation grazing system in the Herd Creek tributary to the East Fork of the Salmon River, to reduce cattle grazing on lower elevation sagebrush-grassland and

This study was supported by Idaho Dept. of Fish \& Game, Challis National Forest, Cooperative Fish and Wildlife Research Unit, University of Idaho, and McIntire Stennis Project MS-22, College of Forestry, Wildlife and Range Sciences, University of Idaho. We thank Jim Bennetts, Challis, Ida., for advice and hospitality. This is University of Idaho Forest, Wildlife, and Range Experiment Station Publication 653. Manuscript accepted 6 Oct. 1992. riparian zones. Grazing was delayed until 15 June every third year on these low elevation areas, compared to season-long grazing starting in May prior to implementation of the system. An investigation of the effects of the grazing system on mule deer and elk was initiated in 1975. The area was typical of the steep sagebrush-grass rangeland in east-central Idaho. Important mule decr winter range occurred at lower elevations and elk summer and winter range at higher elevations.

We hypothesized that if implementation of the grazing system was effective in redistributing cattle onto higher elevations and steeper slopes, then elk and mule deer would move to still higher and steeper terrain. In addition, we expected that plant community use by elk and mule deer would differ among pastures depending upon whether cattle were present or absent, and whether the pasture had been grazed or rested that year. Data collection began in January 1975 and continued through December 1979. The longerterm consequence to mule deer and elk using the grazing system was evaluated from population trend and winter distributions obtained by Kratville (1989) and Kuck et al. (1989, 1991).

\section{Study Area}

The 21,590-ha allotment (Fig. 1) has steep terrain with major ridge systems tending north to south. Elevations range from 1,768 $\mathrm{m}$ near the mouth of Herd Creek to 3,325 m on Sheep Mountain. Slopes are commonly $20-30^{\circ}$.

Mean annual temperatures during the 1974-1985 period averaged $6.9^{\circ} \mathrm{C}$. Annual precipitation averagd $190 \mathrm{~mm}$ for the past 30 years at the Challis recording station (elevation $=1,580 \mathrm{~m}$ ) approximately $40 \mathrm{~km}$ from the study area (National Climatological Data Center 1974-1986). Precipitation during the June-August growing season was $71.3 \mathrm{~mm}$ in $1975,57 \mathrm{~mm}$ in $1976,77.8 \mathrm{~mm}$ in $1977,33.5$ $\mathrm{mm}$ in 1978 and $40.8 \mathrm{~mm}$ in 1979. The maximum average snow depth of $181 \mathrm{~cm}$ occurred at Mill Creek Summit (elevation $=2,680$ $\mathrm{m})$ during March or April surveys. The greatest deviation from the 1974-86 average occurred in $1974(255 \mathrm{~cm})$ and $1977(83 \mathrm{~cm})$. The $1977-81$ period was generally below average.

Cattle entry on the early pasture on 15 June was based on average phenology of dominant grass species. Movement to the late pasture occurred after seed set of the dominant grasses (early to mid August). Grazing continued through October, with about 666 cows and a similar number of calves grazing the allotment each year.

Elk use of the allotment increased from 1970 to 1990 . In the 1970 's, about 150 elk used the allotment through the summer into the late fall. From January through April, approximately 20-25 elk, primarily bulls, wintered on ridges in the allotment. The primary winter range for these elk, Willow Creek Summit, carried 45 elk in 1969-70 and 420 elk in 1987-88 (Kuck et al. 1989). In 1985, 299 

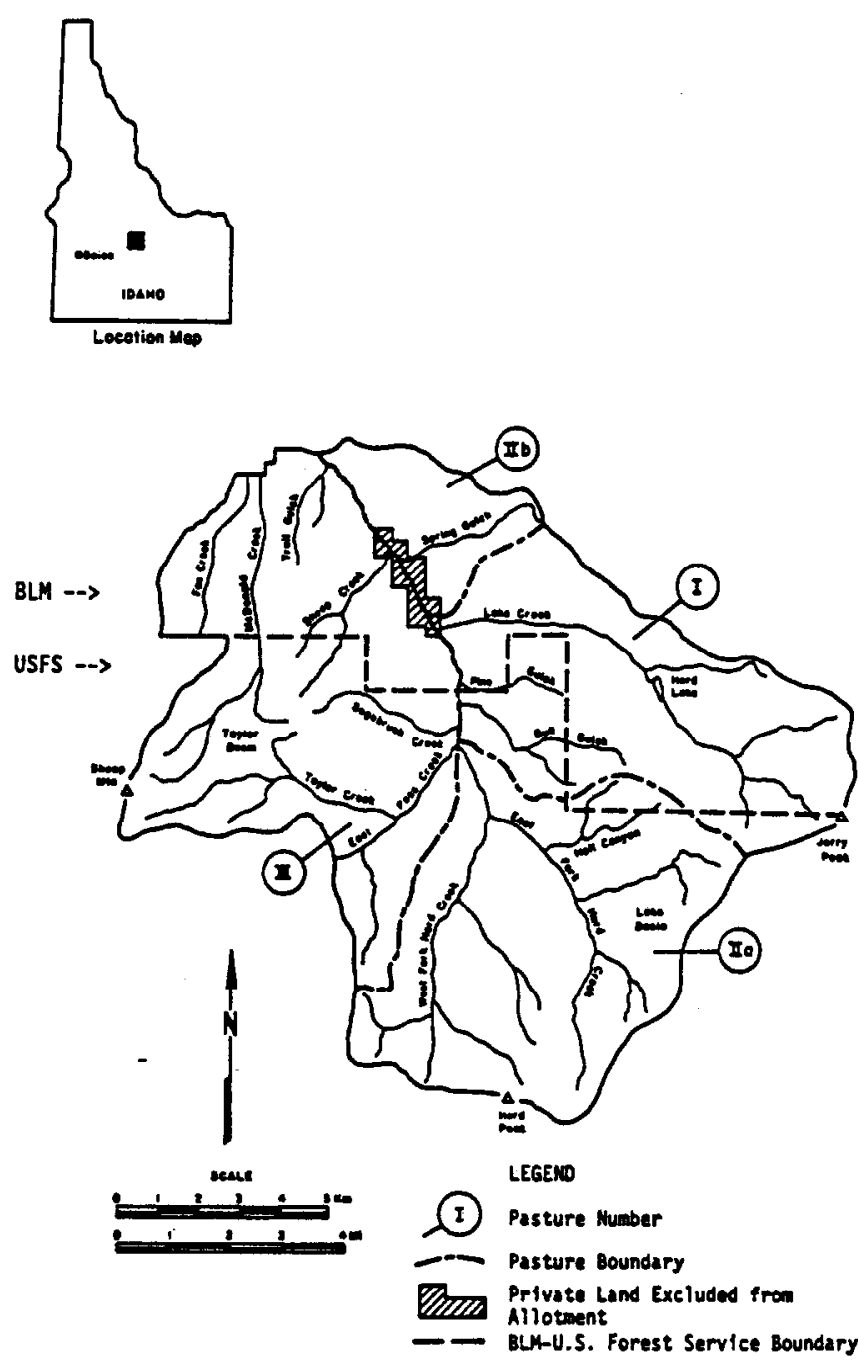

Fig. 1. Herd Creek Allotment study area showing layout of the 3 pasture system and land ownership.

elk were observed summering on the allotment (Idaho Fish and Game Department records, Salmon), double that observed 6 years previously. A group of 14 cows and calves was first seen wintering on ridgetops on the allotment during the 1978-79 winter. An aerial survey in March 1990 revealed 36 elk wintering on the allotment (M. Scott, Idaho Fish and Game Department, pers. comm.).

Mule deer numbers fluctuated from highs in the 1960's to lows in the early 1970's and have slowly increased since (Kuck et al. 1991). Most use of this grazing system by mule deer occurred in winter at lower elevations, with few deer remaining on the area in summer. During the study, $300-400$ mule deer wintered on the allotment.

Sagebrush-dominated communities occupied $82 \%$ of the allotment. Habitat types follow Hironaka et al. (1983) and Mueggler and Stewart (1980), but differences from the habitat types they described were encountered. We categorized plant communities into 6 community types, using 2 to 4 permanently marked sites established within representative stands of each community. Trends in canopy coverage of important species and density of big sagebrush were reported by Yeo et al. (1990).

Wyoming big sagebrush (Artemisia tridentata ssp wyomingensis Nuttall) occupied $32 \%$ of the allotment at lower elevations. On southerly aspects, bluebunch wheatgrass (Agropyron spicatum Scribner and Smith) was a codominant but other grasses and forbs were sparse. This community corresponded to the Wyoming big sagebrush/bluebunch wheatgrass community reported by Hiron- aka et al. (1983). On northerly aspects, Wyoming big sagebrush and bluebunch wheatgrass occurred with Sandberg's bluegrass (Poa secunda Vasey) as a codominant. Forbs were more common than on southerly aspects.

Threetip sagebrush (Artemisia tripartita Rydberg) occurred as a mid-elevational band on northerly aspects above Wyoming big sagebrush communities. We considered this community type the threetip sagebrush/Idaho fescue (Festuca idahoensis Elmer) community described by Hironaka et al. (1983) and Mueggler and Stewart (1980). This community type covered $3 \%$ of the allotment.

Mountain big sagebrush (Artemisia tridentata ssp. vaseyana Nuttall) occupied the higher elevations of nonforested habitat (45\% of the allotment). Mountain big sagebrush codominated with bluebunch wheatgrass and bluegrasses (Poa spp. L.) on southerly aspects while on northerly aspects it occurred with bluebunch wheatgrass and Idaho fescue. At the highest elevations, bluebunch wheatgrass was no longer present and the dominant grass was Idaho fescue.

Most riparian communities were dominated by willows (Salix spp. L.) with water birch (Betula occidentalis Hooker), quaking aspen (Populus tremuloides Michaux), and cottonwood ( $P$. trichocarpa Torrey \& A. Gray) occasional associates. Mesic meadows at high elevations which had seasonally flowing water were included with riparian communities for analyses. The basin big sagebrush ( $A$. tridentata ssp. tridentata Nuttall)/bluebunch wheatgrass community type (Hironaka et al. 1983) also occurred in major draws and next to riparian communities. Riparian communities covered $4 \%$ of the allotment.

Steele et al. (1981) described forest communities in the region. Coniferous forest types occurred at high elevations generally on northerly slopes and occupied $13 \%$ of the allotment. These consisted of Douglas-fir (Pseudotsuga menziesii Franco), Englemann spruce ( Picea engelmannii Parry), and mixed types of subalpine fir (Abies lasiocarpa Nuttall), lodgepole pine (Pinus contorta Douglas), and limber pine ( $P$. flexilis James).

Other communities were sparsely represented. Low sagebrush ( $A$. arbuscula Nuttall)/Idaho fescue communities were found on flat, gravelly ridges but comprised only $2 \%$ of the study area. Curl-leaf mountain-mahogany (Cercocarpus ledifolius Nuttall) was associated with rock outcrops on all aspects and elevations but occupied less than $1 \%$ of the total allotment.

\section{Methods}

We determined habitat use of elk, mule deer, and cattle on the allotment from fixed-wing aircraft at weekly to biweekly intervals throughout each year ( $n=88$ flights from 1 February 1975 through 10 December 1979). Flight paths systematically followed drainage and ridge patterns so that the entire allotment was searched each flight.

We recorded animals of the same species within $100 \mathrm{~m}$ of each other as a single observation. The total number of observations for cattle was 755 , for elk 369 , and for deer 826 . For each observation we recorded the elevation, plant community, and pasture in which each observation occurred on 1:24,000 topographic quadrants with plant community and pasture boundaries delineated. We estimated slope steepness of each observation in the categories $0-10^{\circ}, 10-20^{\circ}, 20-30^{\circ}, 30-40^{\circ}, 40-50^{\circ}$, and $>50^{\circ}$.

The 3 treatments were: (1) pastures that had not been grazed by cattle since initiation of that year's plant growth at the time observations were obtained (rest), (2) pastures that were being grazed by cattle at the time observations were obtained (with), and (3) pastures that had been grazed by cattle since initiation of that year's growth but which were not occupied by cattle at the time observations were obtained (without). Observations were summed in each of 3 grazing periods for comparison of treatment selection and 
plant community selection among treatments for each year of study. Grazing periods were: (1) summer and fall (16 June-31 October), (2) winter (1 November-15 March), and (3) spring (16 March-15 June).

The frequency of observations of each herbivore species in each community type was summed for each season by year. We compared selection of treatments by elk and mule deer and seasonal use of community types among treatments using a selectivity index (Ivlev 1961) as follows: (observed frequency-expected frequency) $/$ (observed frequency + expected frequency). Values range from 1 to -1 with values $>0$ indicating preference, 0 indicating expected occupancy, and $<0$ indicating avoidance. Expected frequencies for use of each treatment were calculated by multiplying the observed frequencies for each year by the percentage of pasture-months within each treatment for each year (pasture-months = number of pastures undergoing a treatment $\times$ number of months within that treatment for each year). Expected frequencies for each plant community type within each treatment were calculated as the observed frequency of observations within each season multiplied by the respective percent area occupied by each community within the allotment.

We determined average elevation and slope (using mid-points of each slope class) used by each species for each sample date. Responses in range use by mule deer and elk to the grazing system were analyzed with $T$ and chi square tests. Responses of mule deer and elk were compared during the grazing period, winter, and spring. Comparisons were made between pastures that cattle grazed with those not in use during summer. Comparisons of winter and spring range use by mule deer and elk were made between pastures grazed and pastures rested the previous season.

Insufficient observations were obtained to compare community type use of elk and deer. Changes in cattle range use patterns were compared among years using chi-square and analysis of variance tests. Observations of plant community use were weighted based on the relative availability of each community within the pasture occupied.

\section{Results}

\section{Cattle Range Use Patterns}

There were no differences between summer and fall cattle habitat use patterns for the habitat variables measured $(P>0.16)$ so all cattle range use data were combined. Mountain big sagebrush communities received $54 \%$ of the total use over the entire study period, which was comparable to the $45 \%$ availability on the allotment. Riparian zones received $27 \%$ of total use, disproportionately more than the $4 \%$ availability. Differences in habitat use patterns among years were significant (Fig. 2). In 1976, cattle used riparian communities more and mountain big sagebrush communities less than in subsequent years. Wyoming big sagebrush/bluebunch wheatgrass communities received significantly more use in 1976 than in subsequent years, likely attributable to grazing the low-elevation pasture late, where substantial stands of this community occurred. Additionally, the $57 \mathrm{~mm}$ of precipitation falling in September 1976, the largest monthly total during the study, may have contributed to the use of this community.

Cattle used increasingly higher elevations in each successive year ( $P=0.0001$ ), with significant differences between the $1975-77$ period and the 1978-79 period. From 1975 through 1977, use was between 2,240 and $2,360 \mathrm{~m}$ while in 1978 and 1979 , cattle used slopes ranging from $2,375 \mathrm{~m}$ to $2,475 \mathrm{~m}$. Slopes less than $20^{\circ}$ received $79 \%$ of the total observed use by cattle. Cattle also made increasingly greater use of slopes $>20^{\circ}$ from 1976 through 1979 (Fig. 3). For the entire study, 50\% of cattle observations were in draws, $29 \%$ on benches and subridges, and $21 \%$ on open slopes.

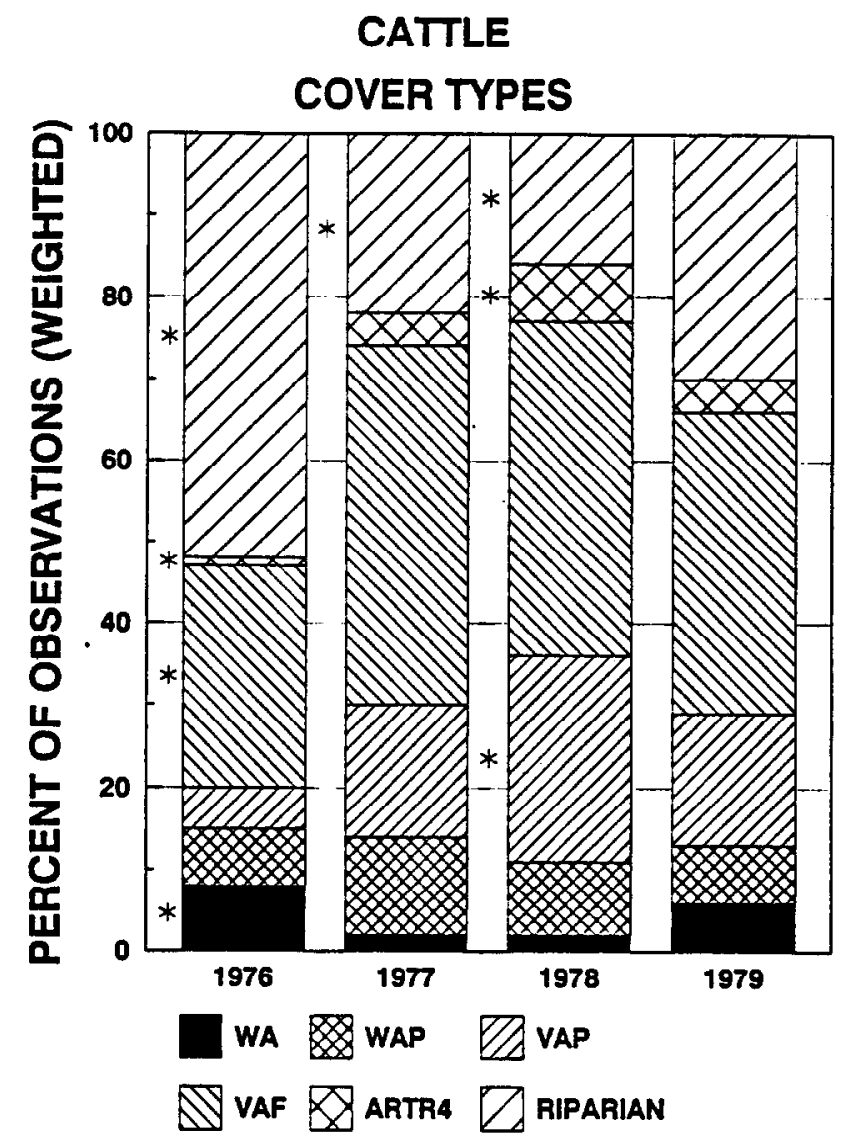

Fig. 2. Cattle use of the 6 major nonforested plant communities on the Herd Creek allotment, 1976-1979. The frequency of observations within each community were weighted by the relative availability of the community within each pasture. Segments of each bar marked by an * are significantly different than expected $\left(\mathrm{X}^{2}\right.$ with 1 degree of freedom, $P<0.05$ ). Plant communities include: $\mathbf{W A}=$ Wyoming big sagebrush/ bluebunch wheatgrass, WAP = Wyoming big sagebrush-bluebunch wheatgrass-Sandberg bluegrass, VAP = Mountain big sagebrushbluebunch wheatgrass-Sandberg bluegrass, VAF = Mountain big sagebrush-bluebunch wheatgrass, Idaho fescue, ARTR4 = Threetip sagebrush.

\section{Elk Range Use Patterns}

During the summer-fall grazing period, elk use of plant communities within rested pastures was different from use of grazed pastures during the grazing season (Table 1). Mountain big sagebrush/bluebunch wheatgrass/Idaho fescue received greatest use by elk during summer and fall. Mountain big sagebrush/bluebunch wheatgrass/Idaho fescue was used more extensively in rested pastures than in grazed pastures. Use of forest and riparian communities in rested pastures was almost half of the use observed in grazed pastures in summer-fall. Use of forested communities showed similar trends in winter, but no elk were observed in forested areas on grazed lands in spring. Elk use in winter was primarily on mountain big sagebrush communities, with mountain big sagebrush/bluebunch wheatgrass/bluegrass communities used more on grazed pastures, and mountain big sagebrush/bluebunch wheatgrass/Idaho fescue communities used more on rested pastures. Use of mountain big sagebrush communities remained high in spring. Riparian communities received 3 times the use on both rested and grazed pastures than would be expected according to availability.

Elk use of the highest elevations, steep slopes, and forested communities was greater in grazed pastures than ungrazed pastures. Within grazed pastures, $41 \%$ of elk observations were on 
CATTLE

SLOPE STEEPNESS (DEGREES)

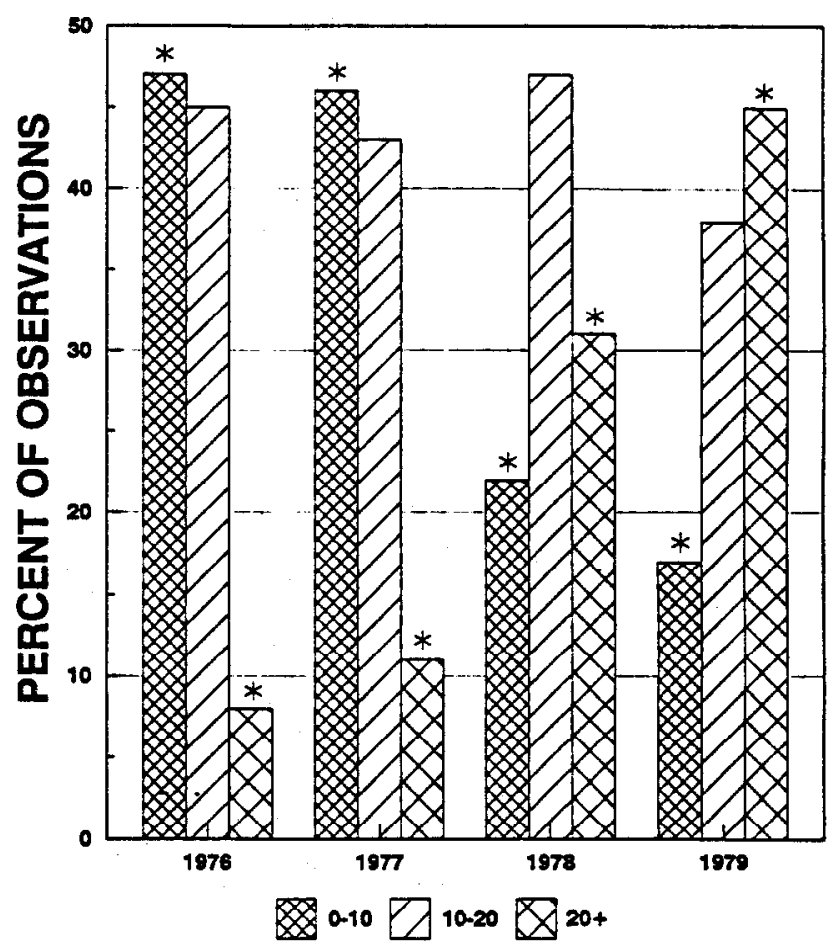

Fig. 3. Changes among years of percentage of cattle groups observed within 3 slope steepness categories. Bars topped by an * are significantly different than expected ( $X^{2}$ with 1 degree of freedom, $\left.P<0.05\right)$.

slopes $>20^{\circ}$, while in rested pastures, $20 \%$ of elk observations were on slopes that steep. Within grazed pastures elk made less use of benches and were located more in draws and on spur ridges than in rested pastures. Within rested pastures, elk were distributed evenly among slope classes, but within pastures grazed the previous summer, elk use was greater on steeper slopes ( $76 \%$ of observations on slopes $>10^{\circ}$ ). Elk made greater use of draws in rested pastures and greater use of slopes in grazed pastures in spring.

Elk selected rested pastures and avoided pastures with cattle present 4 of the 5 years following implementation of the grazing system (Fig. 4a). The greatest differences occurred in 1975, the least in 1979 , suggesting that elk may have been adjusting to the presence of cattle as the grazing system continued in operation. Elk avoided pastures grazed previously that season by cattle in 3 of the 5 years. Deviations from that pattern occurred in 1977 when elk selected pastures with cattle present and in 1978 when elk avoided rested pastures.

\section{Mule Deer Range Use Patterns}

Mule deer habitat use patterns did not differ between rested and grazed pastures during summer and fall (Table 2). In winter, deer made greater use of mountain big sagebrush/bluebunch wheatgrass/bluegrass and mountain big sagebrush/bluebunch wheatgrass/Idaho fescue communities in rested pastures (76\%) than in grazed pastures $(40 \%)$. Within rested pastures, deer were observed at higher elevations than in grazed pastures. Mule deer used draws more frequently and benches less frequently in rested pastures than in grazed pastures.

In spring, deer used plant communities similarly in rested and grazed pastures, although Wyoming big sagebrush/bluebunch wheatgrass/Sandberg's bluegrass and mountain big sagebrush/bluebunch wheatgrass/Idaho fescue communities received slightly greater use in rested pastures. Deer used steeper slopes in grazed pastures than in rested pastures, and were seen more frequently in
Table 1. Elk habitat use in rested and grazed pastures, Herd Creek Allotment, 1976-79.

\begin{tabular}{|c|c|c|c|c|c|c|}
\hline \multirow[b]{2}{*}{ Habitat variable } & \multicolumn{2}{|c|}{ Summer-Fall } & \multicolumn{2}{|c|}{ Winter } & \multicolumn{2}{|c|}{ Spring } \\
\hline & Rest & Graze & Rest & Graze & Rest & Graz \\
\hline \multicolumn{7}{|l|}{ Plant Community ${ }^{1}$} \\
\hline$n=$ & 66 & 102 & 22 & 25 & 65 & 112 \\
\hline VAP $(\%)$ & 12 & 19 & 32 & 72 & 16 & 32 \\
\hline VAF $(\%)$ & 65 & 39 & 59 & 8 & 59 & 57 \\
\hline VF $(\%)$ & 5 & 8 & 0 & 0 & 0 & 0 \\
\hline RIPARIAN (\%) & 6 & 13 & 0 & 0 & 10 & 12 \\
\hline FOREST $(\%)$ & 12 & 21 & 9 & 20 & 15 & 0 \\
\hline$P=$ & \multicolumn{2}{|c|}{0.03} & \multicolumn{2}{|c|}{$<0.01$} & \multicolumn{2}{|c|}{0.03} \\
\hline
\end{tabular}

Slope Steepness $\left({ }^{\circ}\right)$

$n=$

$0-10(\%)$

$10-20(\%)$

$\geq 20(\%)$

$P=$

\begin{tabular}{lr}
66 & 101 \\
45 & 24 \\
35 & 34 \\
20 & 41 \\
\multicolumn{2}{c}{$<0.01$}
\end{tabular}

\begin{tabular}{lrr}
22 & & 25 \\
36 & & 28 \\
46 & & 28 \\
18 & & 44 \\
\multicolumn{2}{|c}{0.16} &
\end{tabular}

$\begin{array}{rrr}65 & 112 \\ 36 & 23 \\ 31 & 49 \\ 33 & & 27 \\ & 0.03 & \end{array}$

Slope Character

$n=$

sub-ridge (\%)

draw $(\%)$

bench $(\%)$

face $(\%)$

$P=$

$\begin{array}{lr}65 & 98 \\ 11 & 14 \\ 18 & 33 \\ 48 & 19 \\ 23 & 34 \\ <00.01 & \end{array}$

$\begin{array}{lrr}24 & 31 \\ 25 & & 39 \\ 25 & & 19 \\ 25 & & 10 \\ 25 & & 32 \\ & 0.37 & \end{array}$

$\begin{array}{lr}66 & 124 \\ 12 & 15 \\ 39 & 19 \\ 29 & 41 \\ 20 & 25 \\ & 0.03\end{array}$

Elevation (m)

$n=$
mean
$\pm S E$
$P=$

\begin{tabular}{rrcrrr}
66 & 107 & 22 & 27 & 70 & 128 \\
2479 & 2555 & 2433 & 2444 & 2464 & 2390 \\
\pm 20 & \pm 15 & \pm 28 & \pm 29 & \pm 15 & \pm 12 \\
$<0.01$ & \multicolumn{2}{c}{0.78} & \multicolumn{2}{c}{$<0.01$} \\
\hline
\end{tabular}

IVAP = mountain big sagebrush $/$ bluebunch wheatgrass $/$ bluegrass,

$\mathrm{VAF}=$ mountain big sagebrush/bluebunch wheatgrass/Idaho fescue,

$V F=$ mountain big sagebrush $/$ Idaho fescue

draws in rested pastures and on slope faces in grazed pastures.

Mule deer use of pastures was consistent 4 of the 5 years of study. Mule deer selected pastures grazed by cattle previously that season and avoided rested pastures and pastures with cattle present in all years except 1977 (Fig. 4b). During 1977 the pattern was opposite. Snow depths were $75 \%$ below normal in winter 1976-77 and the lowest elevation pasture was rested during 1977 . The degree of selection remained similar among years except in 1977 when indices were generally smaller.

\section{Discussion}

Cattle responded to implementation of the grazing system as Hormay and Talbot (1961) predicted. Higher concentrations of cattle within pastures and efforts to redistribute grazing by water development, salting, and herding resulted in increased use of steeper slopes, higher elevations, and broader distribution among habitats. Cattle appeared to respond more to these efforts as the grazing system continued.

While elk habitat use patterns appeared to be affected by cattle grazing pattern and intensity, elk population trends were not considered to be similarly related. The conservative harvest of cow elk over the past 2 decades (Kuck et al. 1989) was likely the primary reason for the population increase. Since elk preferred ungrazed pastures and sites not used by cattle, the amount of overlap in grazed pastures was reduced, and use of rested pastures, which were grazed by cattle early the next year, was increased. Additionally, elk may have been adiusting to the system by making greater use of pastures with cattle present and pastures previously grazed by cattle, although preference for pastures without cattle continued for at least 5 additional years (Kratville 1989). Changes in elk population size or changes in the grazing pattern by cattle would affect these relationships.

Shifts in habitat use by elk on the allotment when cattle were not 

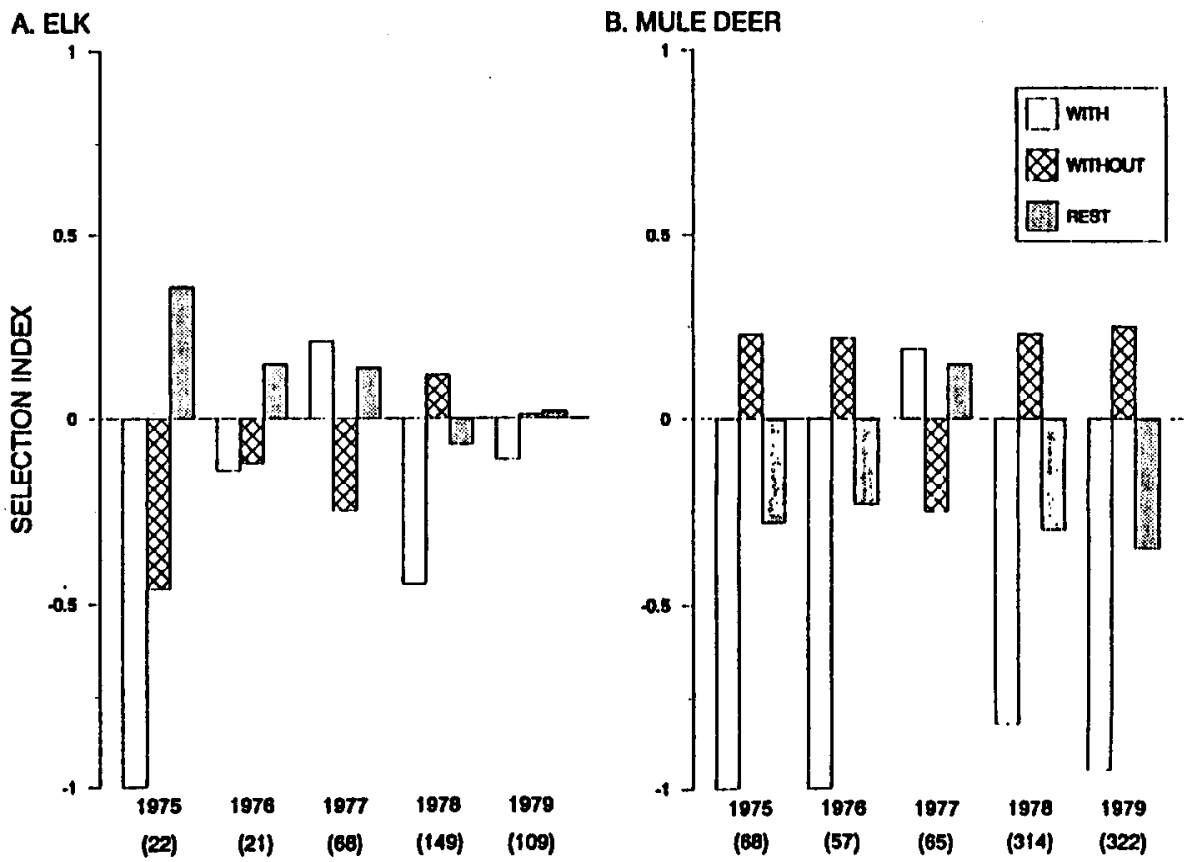

Fig. 4. Elk and mule deer selection of 3 grazing treatments on the Herd Creek Allotment, 1975-1979. Numbers in parentheses are the number of observed groups. Methods section explains grazing treatments and selection index.

Table 2. Mule deer habitat use in rested and grazed pastures, Herd Creek Allotment, 1976-79.

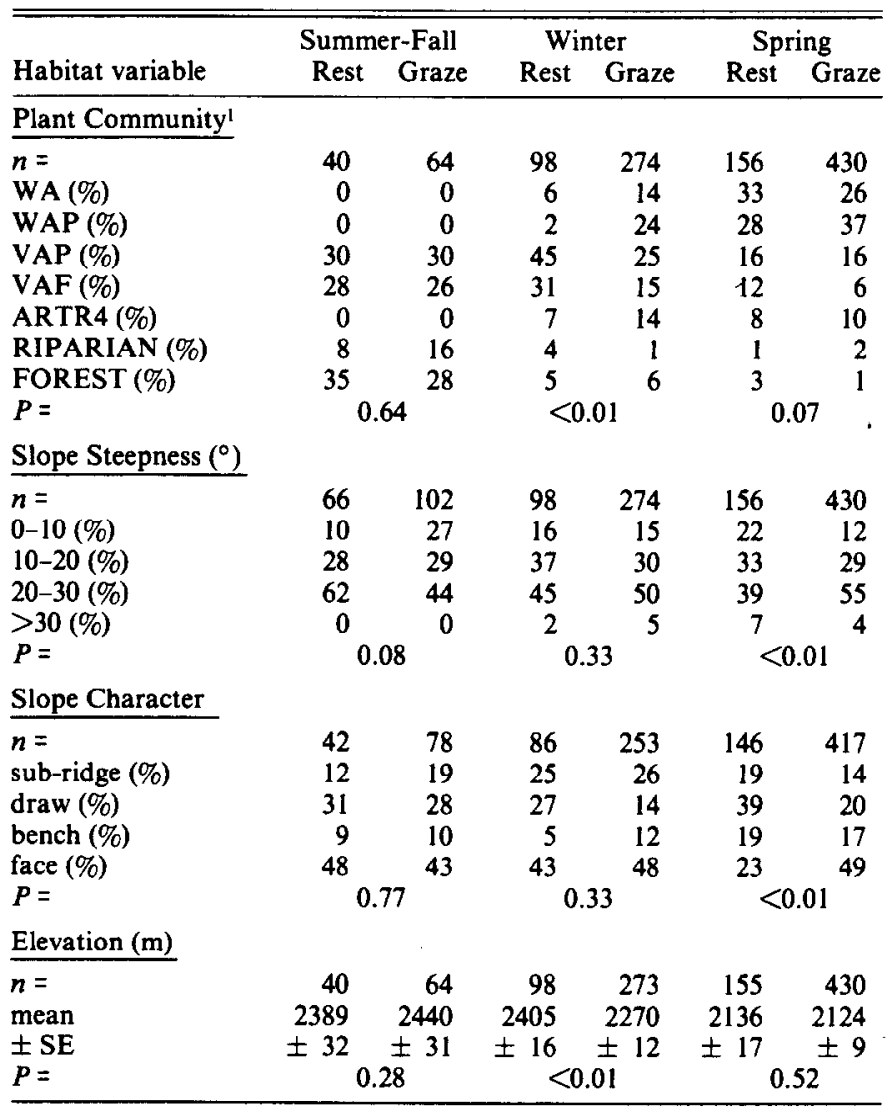

WA $=$ Wyoming big sagebrush/bluebunch wheatgrass,

WAP = Wyoming big sagebrush/bluebunch wheatgrass $/$ Sandberg's bluegrass

VAP = mountain big sagebrush/bluebunch wheatgrass/bluebunch,

VAF = mountain big sagebrush/bluebunch wheatgrass/Idaho fescue

ARTR4 = three-tip sagebrush/Idaho fescue present may be related to changes in forage availability and palatability as well as disturbance. High frequencies of grazed plants occurred on level areas, lower slopes, and near water and cover (Yeo et al. 1990). Limited use of the more heavily grazed sites by elk observed in this study was also observed by Skovlin (1968). However, increased use of mountain big sagebrush/bluebunch wheatgrass/Idaho fescue communities by elk in winter following cattle grazing the previous season may reflect reductions in disturbance.

Three short-term responses of elk to cattle grazing have been observed. First, elk may select pastures where regrowth following cattle grazing occurs (Anderson and Scherzinger 1975, Grover and Thompson (1986), Alt et al. 1992). The regrowth may provide more palatable forage than the adjacent ungrazed growth (Pitt 1986). Second, pastures currently being grazed by cattle may receive less use than ungrazed pastures (Skovlin et al. 1968, Mackie 1985, Boyce 1989, Frisina 1992, this study). Third, elk may not prefer to use previously grazed pastures either later in the same year or the subsequent year (this study). This may occur in areas where habitat overlap and seasonal use patterns preclude use of regrowth by elk, or where regrowth may not occur due to drought or the prevailing moisture pattern. Elk grazed Herd Creek primarily at the same time cattle were using it, while on the other areas, elk grazed after cattle had left. At Herd Creek, elk used different areas in winter than cattle did during the grazing season, primarily due to snow accumulations which made areas grazed by cattle unavailable. Regardless, the observed shifts were not detrimental to elk. Cattle have not made much use of areas occupied by elk until July, well after elk calving and near the period when calves were weaned. Also, sufficient ungrazed area was available for elk within and adjacent to the allotment to provide adequate habitat.

We observed elk feeding with cattle or within $25 \mathrm{~m}$ of cattle on summer and fall ranges when humans were not present. Human activities associated with monitoring the cattle, rather than the cattle themselves, may be responsible for the shifts in elk use. Human-caused disturbance was typically short-lived but frequent on this system, and the reaction by elk appeared to be similar to disturbance caused by persistent logging or recreational activity (Ward 1973, Hershey and Leege 1976).

Winter ranges for elk typically were limited to ridge systems at high elevations. Use by cattle of ridgetops used by elk in winter may 
reflect improved forage quality on these sites attributable to elk grazing. Placement of salt below ridges on northerly aspects which were inaccessible to elk during most winters, would help to minimize grazing pressures by both cattle and elk on the ridges, assuming elk populations will be limited by hunting. These wintering sites may be useful to index vegetation trends in relation to elk population size on this area.

Since mule deer did not appreciably alter habitat use patterns in relation to cattle grazing, effects of the grazing system seemed less noticeable than for elk. Use of lower elevations on grazed pastures in spring and greater use of draws in rested pastures in winter and spring suggest mule deer may have been attracted to the increased forage base occurring on these sites. Deer are known to prefer ungrazed portions of their ranges (Dusek 1975, Wallace and Krausman 1987, Loft et al. 1991, Ragotzkie and Bailey 1991), but light grazing by cat tle may enhance forage availability (Willms and McLean 1978, Willms et al. 1981). As with elk, suitable habitat was sufficiently available within the system for mule deer.

The slow changes in mule deer populations may be related to the climate of the region, augmented by declines in the sagebrush which serves as winter forage, rather than hunter harvest, which has remained low in recent years (Kuck et al. 1991). An apparent decreasing ability of this area to support mule deer because of declines in sagebrush (Yeo et al. 1990) may be somewhat offset by increases in abundance and palatability of important spring forage species such as Sandberg's bluegrass and bluebunch wheatgrass. This may be especially evident when snow depths allow access to the lower growing forages which may reduce the importance of sagebrush in the diet. The light grazing which could enhance forage availability for mule deer in spring could also help offset the decline in sagebrush. Mule deer populations will likely remain lower than 1960 levels, unless current vegetation trends are altered.

Long-term responses of big game to the grazing system would be attributable primarily to vegetation change, and secondarily to population levels which may be related primarily to hunting pressure. The major conclusion from this study is that implementation of the grazing system merely inserted additional interactions to an already complex ecological system. Both mule deer and elk responded predictably in terms of habitat use to changes brought on by the grazing system, but no changes in population size attributable to the system were evident for either species. Obviously, other limiting factors, especially hunter harvest, affect population trends of mule deer and elk in this area.

Benefits to mule deer and elk from rearranged grazing systems may occur if they are planned for and vegetation, climate, and terrain allow. However, there will be situations, like those of this investigation, where elk and mule deer populations may adjust habitat use without other effect, while goals concerning livestock and rangeland conditions are met.

\section{Literature Cited}

Alt, K.L., M.R. Frisina, and F.J. King. 1992. Coordinated management of elk and cattle, a perspective-Wall Creek Wildlife Management Area. Rangelands 14:12-15.

Anderson, W.E., and R.J. Scherzinger. 1975. Improving quality of winter forage for elk by cattle grazing. J. Range Manage. 28:120-125.

Boyce, M.S. 1989. The Jackson elk herd. Cambridge Univ. Press, N.Y

Dusek, G.L. 1975. Range relations of mule deer and cattle in prairie habitat. J. Wildl. Manage. 39:605-616.

Frisina, M.R. 1992. Elk habitat use within a rest-rotation grazing system. Rangelands 14:93-96.

Grover, K.E., and M.J. Thompson. 1986. Factors influencing spring feeding site selection by elk in the Elkhorn Mountains, Montana. J. Wildl. Manage. 50:466-470.

Hershey, T.J., and T.A. Leege. 1976. Influences of logging on elk on summer range in north-central Idaho, p. 73-80. In: S.R. Heib (ed.). Elk-Logging Roads Symp. Forest, Wildl. and Range Exp. Sta., Univ. Idaho. Moscow.
Hironaka, M., M.A. Fosberg, and A.H. Winward. 1983. Sagebrush-grass habitat types of southern Idaho. Univ. Idaho Forest, Wildl. and Range Exp. Sta. Bull. 35. Moscow.

Holechek, J.L., R.D. Pieper, and C.H. Herbel. 1989. Range management: Practices and principles. Prentice Hall, Englewood Cliffs, N.J.

Hormay, A.L., and M.W. Talbot. 1961. Rest-rotation grazing. A new management for perennial bunch grass ranges. USDA Forest Serv., Prod. Res. Rep. 51.

Ivlev, V.S. 1961. Experimental ecology of the feeding of fishes. Yale Univ. Press, New Haven, Conn.

Julander, O., and D.E. Jeffery. 1964. Deer, elk, and cattle range relations on summer range in Utah. Trans. N. Amer. Wildl. and Nat. Resour. Conf. 29:404-414.

Kratville, S.P. 1989. Elk habitat selection, distribution, and nutrition as influenced by cattle in east-central Idaho. M.S. Thesis, Univ. Montana, Missoula.

Kuck, L., and L. Nelson. 1991. Statewide surveys and inventory. Final Rep. Proj. W-170-R-15 Mule deer. Idaho Dep. Fish \& Game, Boise.

Kuck, L., L. Nelson, and J. Turner. 1989. Statewide surveys and inventory. Job Prog. Rep. Proj. W-170-R-13, Elk. Idaho Dep. Fish and Game, Boise.

Kvale, C.T. 1981. Mule deer, elk, and cattle relationships on the Herd Creek rest-rotation grazing system, East Fork of the Salmon River, Idaho. M.S. Thesis, Univ. Idaho, Moscow.

Loft, E.R., J.W. Menke, and J.G. Kie. 1991. Habitat shifts by mule deer: the influence of cattle grazing. J. Wildl. Manage. 55:16-26.

Mackie, J.R. 1970. Range ecology and relations of mule deer, elk and cattle in the Missouri River Breaks, Montana. Wildl. Monogr. 20.

Mackie, J.R. 1978. Impacts of livestock grazing on wildlife ungulates Trans. N. Amer. Wildl. and Nat. Resour. Conf. 43:462-476.

Mackie, J.R. 1985. The elk-deer-livestock triangle, p. 45-49. In: G.W. Workman (ed.), Western Elk Management. Symp. Logan, Utah.

Mueggler, W.F. 1965. Cattle distribution on steep slopes. J. Range Manage. 18:255-257.

Mueggler, W.F., and W.L. Stewart. 1980. Grassland and shrubland habitat types of western Montana. USDA Forest Serv. Gen. Tech. Rep. INT-66.

National Climatological Data Center. 1974-1986. Climatological data annual summaries, Idaho. Vols. 78-89. National Oceanic and Atmospheric Administration. Washington, D.C.

Pitt, M.D. 1986. Assessment of spring defoliation to improve fall forage quality of bluebunch wheatgrass (Agropyron spicatum). J. Range Manage. 39:175-181.

Kagotzkie, K.E., and J.A. Bailey. 1991. Desert mule deer use of grazed and ungrazed habitats. J. Range 44:487-491.

Skovlin, J.M., P.J. Edgerton, and R.W. Harris. 1968. The influence of cattle management on deer and elk. Trans. N. Amer. Wildl. and Nat. Resour. Conf. 33:169-181.

Steele, R., R.D. Pfister, R.A. Ryker, and J.A. Kittams. 1981. Forest habitat types of central Idaho. USDA Forest Serv., Gen. Tech. Rep. INT-114.

Stoddart, L.A., A.D. Smith, and T.W. Box. 1975. Range management, 3rd ed. McGraw-Hill Book Co., N.Y.

Urness, P.J. 1990. Livestock as manipulators of mule deer winter habitats in northern Utah. USDA Forest Serv. Gen. Tech. Rep. RM-194.

Wallace, M.C., and P.R. Krausman. 1987. Elk, mule deer, and cattle habitats in central Arizona. J. Range Manage. 40:80-83.

Ward, A.L. 1973. Elk behavior in relation to multiple uses in the Medicine Bow National Forest. Proc. West. Assoc. State Game \& Fish Comm. 53:125-141.

Western Association of State Game and Fish Commissioners. 1974. Resolution 12, Improvement of rest-rotation grazing practices. Proc. West. Assoc. State Game \& Fish Comm. 54:400.

Willms, W., and A. McLean. 1978. Spring forage selection by tame mule deer on big sagebrush range, British Columbia. J. Range Manage. 31:192-199.

Willms, W., A.W. Bailey, A. McLean, and R. Tucker. 1981. The effects of fall defoliation on the utilization of bluebunch wheatgrass and its influence on the distribution of deer in the spring. J. Range Manage. 34:16-18.

Wittinger, W.T. 1978. Habitats, food habits, and range use of mule deer, elk, and cattle on the Herd Creek rest-rotation system, East Fork of the Salmon River, Idaho. M.S. Thesis, Univ. Idaho, Moscow.

Yeo, J.J., J.M. Peek, and W.T. Wittinger. 1990. Vegetation changes on a rest-rotation grazing system. Rangelands 12:220-225. 